\title{
Selling the colonial spa town: The contested therapeutic landscapes of Lisdoonvarna and Te Aroha
}

\author{
Ronan Foley $^{\mathrm{a} *}$, Abbey Wheeler ${ }^{\mathrm{b}}$ and Robin Kearns ${ }^{\mathrm{b}}$ \\ ${ }^{a}$ Department of Geography, Rhetoric House, National University of Ireland Maynooth, \\ Maynooth, County, Kildare, Ireland; ${ }^{b}$ School of Environment, The University of Auckland, \\ Private Bag 92019, Auckland, New Zealand
}

\begin{abstract}
The spa town is one of the foundational sites in the study of therapeutic landscape. As settings in which health informs the production of place and in which place is shaped by reputational associations with healing, spa towns have distinctive health and historical geographies. Drawing on a comparison between two spa towns, Te Aroha in New Zealand and Lisdoonvarna in Ireland, a number of critical therapeutic landscapes themes are explored. Two themes in particular are studied in empirical depth, the first being the commodification of health and place within common spa town narratives from the mid-nineteenth century to the early- to mid-twentieth century. A second core theme concerns itself with the contested identities of the watering-place, in relation to the relative importance of health over social identities and in framing native inhabitations against wider colonial place productions. In the tangled narratives of both towns' health histories, we argue there is much to be learned about spatial similarities and variations in a process whereby place is commodified and sold on its reputational therapeutic characteristics. This is a process with local socio-cultural variation but with an additional potential for global-local narratives which moves beyond the spa town to wider watering-place forms.
\end{abstract}

Keywords: therapeutic landscapes; Ireland; New Zealand; health geography; commodification; healing waters

\section{Introduction}

Lisdoonvarna, in County Clare on the west coast of Ireland and Te Aroha, on the eastern edge of the Hauraki-Waikato plains in New Zealand, are two distant locations that share a series of commonalities. Both feature sets of historic buildings framed by the natural mineral waters around which they were initially constructed. They now exist as contemporary replicas of the Victorian spa town. Both are examples of what health geographers refer to as therapeutic landscapes, places that have achieved lasting reputations for providing physical, mental and spiritual healing (Kearns and Gesler 1998). In their roles as therapeutic landscapes, deeper and contested relationships between health and place can be identified, while both towns can be described as contemporaneously 'typical and unique' (Strang 2004). Their relative typicality and uniqueness will form an essential part of our narrative, but also point towards how the colonial spa town was a metaphor for contested understandings of a traditional therapeutic landscape form (Williams 2007).

*Corresponding author. Email: Ronan.Foley@nuim.ie 
In this paper, we explore narratives of these towns' historical development and wider themes around the commodification of health-in-place. Our rationale is that similarities are often observable across different examples of therapeutic landscapes in terms of their structural processes and experiential expressions (Geores 1998, Gesler 2003). Our intention is to examine a set of health histories in place, through co-considering two places on different sides of the world with similar provenance. We contend that, notwithstanding their cultural and spatial distance, the examples of Te Aroha and Lisdoonvarna reflect ways in which the spa town was developed within a global template during the nineteenth century. While local cultural forms shape such spaces, we maintain that they are also part of wider global cultural networks, in these cases, the British Empire. To us, it is instructive to consider the different ways in which such local-global networks operated. Through this dual case-study approach, we offer an advance on many singular studies of therapeutic landscapes which are carried out in isolation, or within individual jurisdictions. In a comparative study, we argue, there is also much to be learned about spatial similarities and variations in a process whereby place is commodified and sold on its reputational therapeutic characteristics.

The paper is laid out as follows. Initially the concept of the therapeutic landscape is introduced, to clarify associations between health and place. As a classic example of such a landscape, the literature discussing the spa town will then be examined, from which two broad themes will be drawn relating specifically to the commodification of the spa town, and the contested identities associated with such settings. The histories of the two study towns, Te Aroha and Lisdoonvarna are then briefly outlined before the sources and methods used in the study are noted. The empirical heart of the paper illustrates the thematic concerns with commodification and contested identity, noting the similarities and differences apparent within both settings. Finally, discussion and conclusion sections identify a set of theoretical and applied ideas from which wider work on the spa town as a representative therapeutic landscape could be developed.

\section{The spa town as therapeutic landscape}

The therapeutic landscape concept has, since its initial introduction by Gesler (1993), developed as a significant focus within health geography as well as influencing disciplines such as anthropology (Williams 2007, Lea 2008). With theoretical foundations in cultural ecology, structuralism and humanism, the idea offers a conceptual and analytical framework for natural, built, social and symbolic environments as they pertain to healing or well-being in place (Williams 1999). Initial studies focused on European locations famed for their healing powers, including spas and religious-spiritual sites (Gesler 1996). Other foundational landscapes included natural settings for asylums and retreats as well as wilderness settings that emphasised more phenomenological connections to healing in place (Tuan 1974, Williams 1998, Palka 1999). More recent debates within the field have contested earlier understandings of the term. In particular, Conradson (2005) identifies the notion of a therapeutic experience and suggests that places and landscapes offer healing through individual experiential engagements in place, but that these can equally be negative or health-endangering. This perspective is strongly linked to the notion of places as generating contested behaviours. Collins and Kearns 
(2007) identify the beach as a good example of a landscape which can potentially both enhance (through exercise, fresh air and retreat) and damage (through drownings and melanoma) health.

While the focus of this paper is on the traditional therapeutic landscape of the spa town there are traces of this contested understanding of health to be found in such settings. This is especially true of therapeutic landscapes whose original health/ healing identities shift, as at Bath or Brighton, to new identities where leisure and tourism assume more significant positions (Gesler 1996, Towner 1996, Foley 2010). In such identify shifts, the central roles of local economics and the commodification of health and place are arguably under-emphasised dimensions in therapeutic landscapes research (Williams 2007, Smith and Puczko 2009, Foley 2010). In many settings the explicit marketing of health in place was central to the production and maintenance of their curative reputations.

Spa towns are represented in a range of locations and forms (Porter 1990, Gesler 1993, Smith and Puczko 2009). They date back to the twelfth century city of Spa in modern-day Belgium, and had a long development in mainland Europe through the fifteenth and sixteenth century in towns like Lucca and Bagnères. The period from the end of the seventeenth century to the end of the nineteenth century marked their heyday in Europe and in those global settings shaped by European cultural expansion. Thus spa towns were developed in colonies as far a field as the US, Canada, New Caledonia, Australia and New Zealand (Rockel 1986, Connell 2006). Importantly, the spa tradition combined healing with socio-cultural and class-related practices, so that the spa town developed a complex mix of curative and socialised identities (Mackaman 1998, Gesler 2003). In their construction, promotion and framing of place, such towns also incorporated ensembles of both physical and human landscapes (Foley 2010). Common features of spa towns included the hot, warm and cold mineral springs that provided the core 'medicinal' product, as well as commercial edifices such as hotels, pump-rooms and bath-houses that were built to house and treat visitors and patients. The 'spa town ensemble' also encompassed the development of specific socio-cultural practices. The spa town identity was therefore shaped by curative stories/narratives as well as more liminal social meanings associated with assembly, status and matrimonial prospects (Mackaman 1998).

In a classic example of these combined medical and social-economic dimensions, Geores (1998) discussed the entrepreneurial history of the town of Hot Springs in South Dakota, whose mineral waters were central to its construction in the late 1880s. Here, the metaphor 'Health $=$ Hot Springs' was created, maintained and adapted within historical contexts of class, medical-health thinking, advertising and available technology to attract visitors from afar. The metaphor was embodied throughout the town's history, with health commodified through the restorative power of the waters and wider landscape (Geores 1998). Indeed the notion of a health history was extensively used in Hot Springs, where an earlier identity as an American Indian site of sacred healing featured in its marketing. Other North American spa towns, such as Radium Hot Springs and Saratoga Springs, employed similar narratives (Wightman and Wall 1985, Valenza 2000, Sterngrass 2001). This linking of a discursive connection between older or 'native' health histories associated with the 'place' is reflected to an extent in both our study area towns. Here, the Māori antecedents at Te Aroha and the holy well traditions at Lisdoonvarna were used to legitimise the historic healing power of place 
(Wells 2003, Foley 2010). This legitimisation was therefore invoked in cultural as well as curative terms both of which fed in to the marketing of health in place.

In terms of how spa towns were sold, the typical narrative was one which had a distinctly place-making flavour. In a common sequence of events the healing waters were discovered by entrepreneurs who in turn had those waters tested for their constituent minerals. Once this chemical evidence was in place, the next step was to identify a medical benefit, generally developed through known cures associated with specific minerals. Individual health biographies were then used to 'verify' the cures. Once the biomedical evidence was in place, preliminary accommodation was built to bring in visitors. Over time commercial demand drove the development of not only the built-environment of the spa, but also the social and economic reputation of the associated town (Brockliss 1990, Hamlin 1990, Cossick and Galliou 2006). In the classic example of Bath, earlier Roman and pagan narratives of spiritual healing were linked to chemical testing and curative narratives in the sixteenth century. This shaped the town's development as a medical place which was subsequently strengthened via a calculated commodification based on fashionability, social mixing and cure (Gesler 1998). The specific place of spa medicine was always relatively uncertain, reflecting Porter's astute observation that spa towns represented, 'the hypochondriacal interplay between organic medicine and the half-acknowledged underground realm of the psychosomatic placebo cure' (Porter 1990, p. xi). Over time one can trace a shift in health practices from immersions in, and consumption of, the spa waters to more complex and medicalised hydrotherapy treatments within which technology and referral played a greater role (Foley 2010). While one can distinguish at times between a specific selling of health and a specific selling of place, in most spa towns commodification (selling) and associated marketing and place promotion (telling) were fundamentally co-dependent (Towner 1996). The selling and telling of health-in-place were also represented across time and space in a rolling process of re-selling and re-telling.

While the towns themselves were sold on the health metaphor, wider social narratives and practices were also essential to their contested development. Many social practices associated with the spa town had distinctly unhealthy outcomes that emphasised their parallel liminal reputations (Porter 1990, Urry 2002, Conradson 2005). To elaborate, the more leisure and tourism-based attractions developed around the spa, the more they departed from being solely health-focused and relied instead on narratives of liminality, gluttony, sex and matrimony, wherein the social reputations fed the healing identities and vice versa (Foley 2010). These social practices, an essential part of the spa town image, paradoxically managed to simultaneously deepen and weaken the power of the therapeutic space/place. In considering the traditional therapeutic landscape in this contested way, newer theoretical understandings of the 'pharmacon' (a drug that can both kill and cure) can be applied, wherein different experiences, inhabitations and performances shape a range of therapeutic outcomes (Andrews and Holmes 2007, Collins and Kearns 2007).

A second form of contestation related to how the model of the 'colonial spa' reflected indigenous and local populations and practices. The development of relatively wealthy clienteles, for whom the spa town became a locus of class identity formation was underpinned by a notion of exclusivity (Mackaman 1998). The great European spas, wherein the nobility and aristocracy mixed and deepened their 
identities, were reproduced in global colonial settings with strong class aspirations. Within colonial settings, these exclusive identities were also associated with a range of exclusionary practices around ownership, regulation, power and profit, wherein the local populations had limited access and proscribed roles (Gesler 2003, Kelly 2009, Foley 2010).

In applying these broader theoretical themes to specific spa towns in Ireland and New Zealand, our aim is to examine the processes of telling/selling health and place and assess how similar these processes were across 'colonial' space. In critically examining the factors shaping the (re)production of a commodified construction of health-in-place we also address two associated objectives. First, we examine the tangled narratives of health and place that act as metaphors linked in to material places and which were utilised in the production of both Lisdoonvarna and Te Aroha. These narratives, we contend, provide valuable evidence of both typical and unique processes of therapeutic landscape production, and within such narratives mobile health and place meanings are also identified to illustrate the importance of time, inhabitation and economics. Second, we re-examine the two spa towns in terms of being contested therapeutic settings, wherein conflicting health and leisure practices and identities were mirrored in exclusive and excluding relations between dominant colonial ownerships and historic 'native' meanings and practices. In considering to what extent these contested understandings of a watering-place-forhealth were erased or incorporated into the narratives, we identify wider sociocultural factors which may have applicability for other colonial spaces and places both within Ireland and New Zealand and also in wider jurisdictions.

\section{Settings and method}

\section{Te Aroha}

Te Aroha remains a unique place by virtue of a narrow line of geothermal springs which emerge from a south-west facing slope at the foot of Te Aroha Mountain. Without these special waters, it is unlikely that a settlement of any kind would have endured here (Wells 2003, p. 11).

The rural town of Te Aroha (2006 population: 3,760) is located on the North Island of New Zealand in the eastern Waikato District at the foot of the volcanic mountain of the same name (Figure 1). Originally known to the local Māori as Waipuia, the hot springs on the site became better known during the local gold-rushes in the 1870s. The original Māori landowner, Te Mokena Hau entered into a deal with the Crown in 1878 for entrepreneurs to develop the site and the first hotels were commissioned in the same year. Over time a separate Domain area (Figure 2) was created around the different springs (primarily alkaline with soda, sulphur and chalybeate) and a range of bath-houses, tea-houses and treatment rooms were built. In the town itself, the range of accommodation and services was augmented in 1886 with the arrival of the railway (Wheeler, 2008).

Te Aroha was founded as a premier spa destination for upper-class international visitors. The town was part of an ambitious wider project to establish tourism and spas in colonial New Zealand and was itself based on the spa of Daylesford in Australia (Rockel 1986). Its popularity and reputation peaked in the late 1800s and 


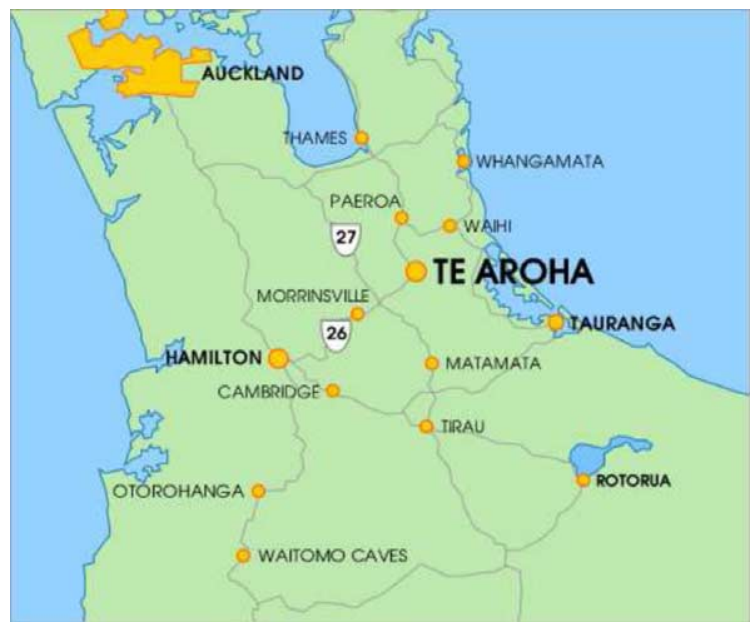

Figure 1. Location map of Te Aroha.

the early decades of the twentieth century. This was followed by a period of decline into the later twentieth century, and a subsequent revitalisation with a heritage orientation. The rural setting and shifts in health-place notions as well as spa culture were additional factors associated with the town's historical development (Rockel 1986, Wells 2003).

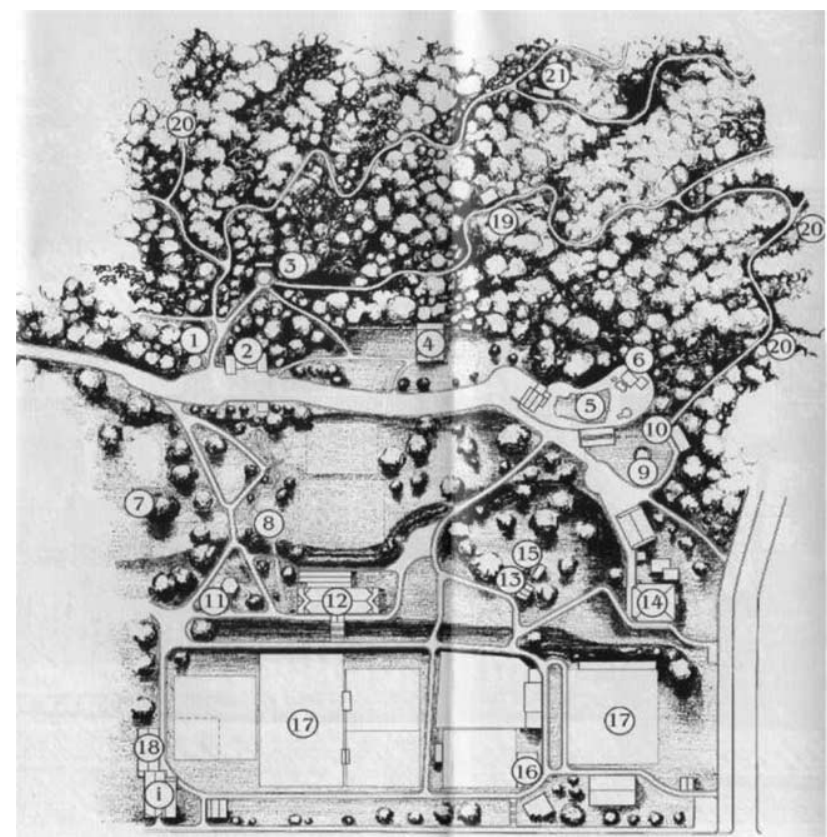

KEY FOK IT AXOHX DOMANN

I. Ingomutiar oino

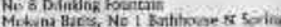

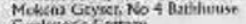
Cimleter a Cortape

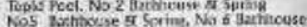
is Soring 5 Shiter 5 No 15 Sprng so sciker 3 Path Lakes 5 Cinati 10 ains twis? if and ionun 12 TeAcubs a Disnic MoseuniCudram

13 NoJ \& No 7 Eathioase

5 Rostioum fe flacary Spaine 18. Metriculopical Starion

TR Prgeta Cooquet Green

S sout

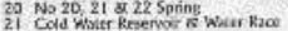

Figure 2. Map of Te Aroha Domain. 


\section{Lisdoonvarna}

There was a very short description of the remote Clare village in Rutty's (1757) guide to the spas of Ireland (Figure 3). Though the waters were known and used, there was little or no development evident in first edition Ordnance Survey maps dating from around 1840. A very intensive period of growth in the 1850 s and 1860 s occurred with 67 houses in place by 1872. By then the town had developed around the roads leading into the square, mainly along the north-south axis, with some development east-west and to the south-east below the main spa (Figure 4). While the town did not initially have an enclosed Domain, the presence of a range of different wells (chalybeate, copper and sulphur) was central to its development, though they were cold rather than hot.

After 1876, Lisdoonvarna developed even more rapidly and with the coming of the West Clare Railway to Ennistymon in 1887, and probably outstripped the most sanguine expectations of Westropp and Stacpoole, the original entrepreneurs associated with its development. The town's peak seems to have been from the $1880 \mathrm{~s}$ through to the 1920s with the decline of the Anglo-Irish clientele being replaced by a partial popularity in the new state. The spa season declined from the 1940s, but its original social identity lives on in the Matrimonial Festival in September, now the focal point of the town's social and economic activity. The waters at the main pump room are still consumed from May to the end of September. There have been unfulfilled plans to revive the treatment rooms, but nothing as active as those at Te Aroha. Outside of the main sulphur well, the other wells have declined. The Double Wells are a relict feature; the Copper Well is inaccessible, while the Twin Wells are usable, but protected behind

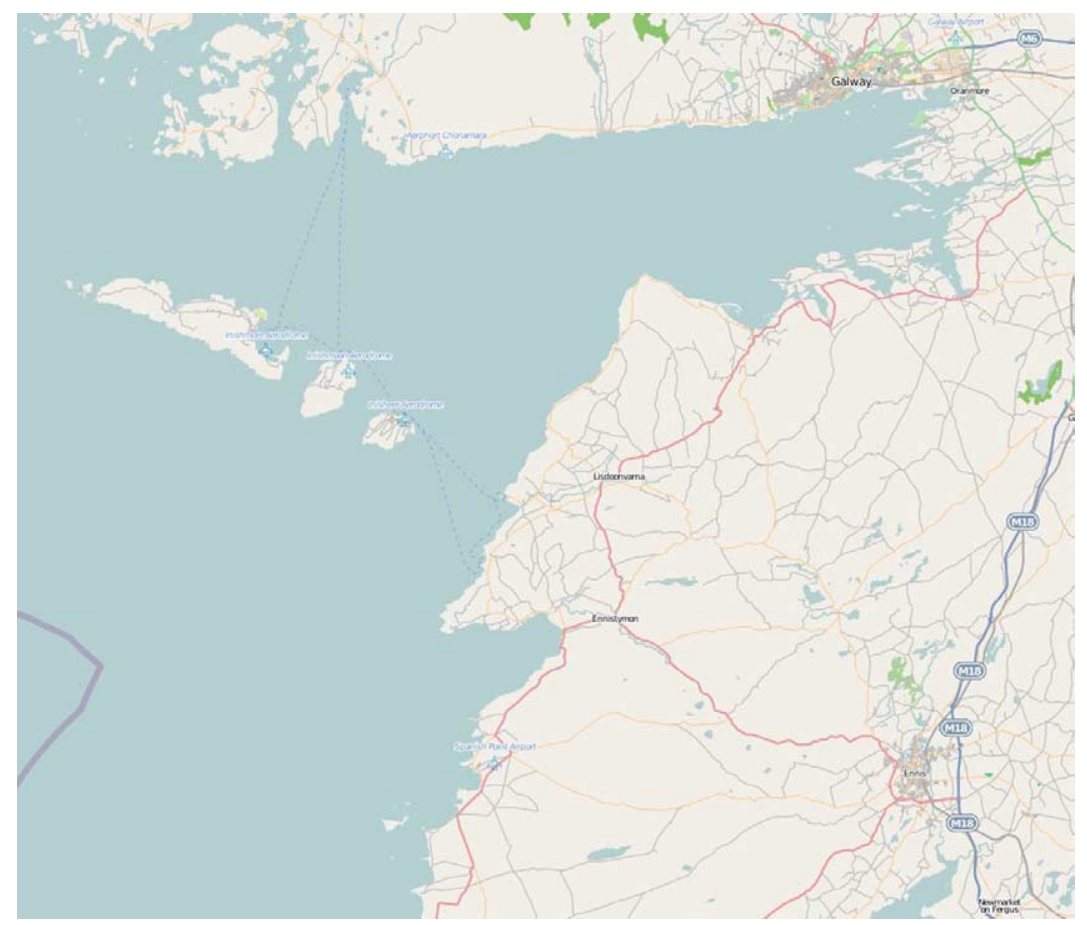

Figure 3. Location map of Lisdoonvarna. 


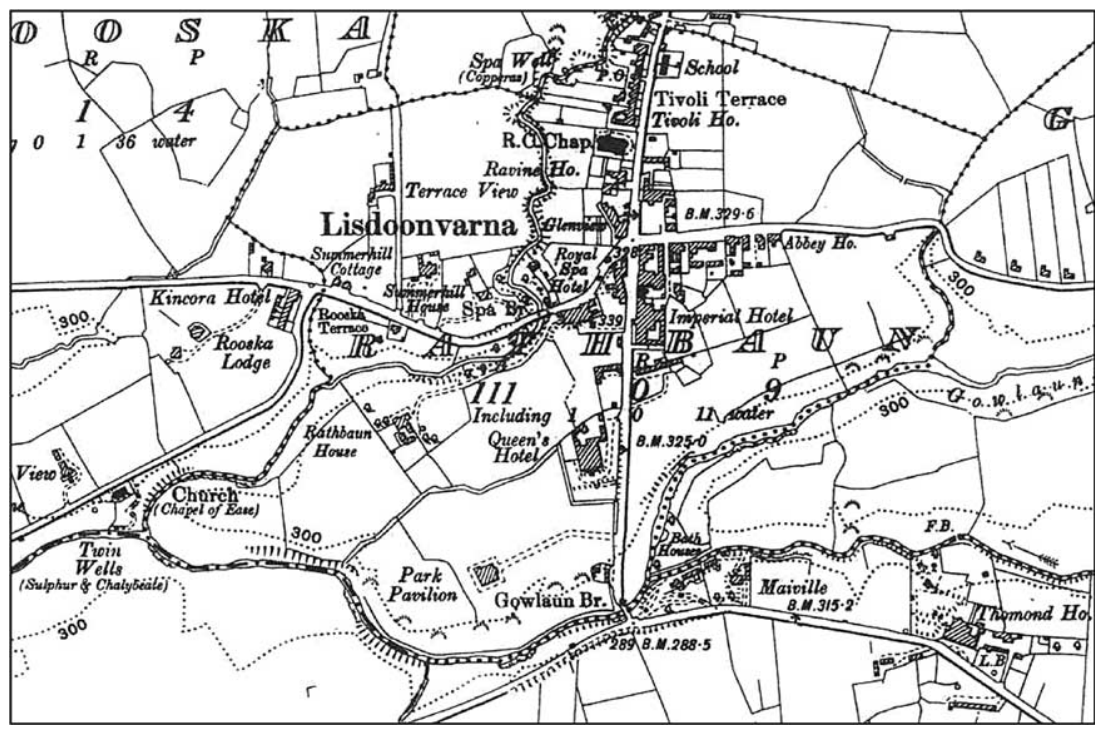

Figure 4. Map of Lisdoonvarna, 1890s.

grilles. The town's identity is evident in surviving hotel names including The Royal Spa, The Imperial, and of course The Hydro (Furlong 2006).

\section{Method}

In the case of both towns, we used a range of secondary material and primary observation to examine the development of the healing places and identify narratives, cures and treatments that made the places. In the case of Te Aroha's evolution as a spa town, and the changing role of its healing reputation and mineral waters, early place-promotional material was investigated, along with more recent publications that reflected the decline of the town and its contemporary survival. Within historical materials and accounts, significant agents who promoted the waters serve as a useful point of analysis and these were supplemented by selected brochures and media publications that confirmed Te Aroha's development, construction and place identity. Historic newspaper, brochure and magazine articles provide secondary data about the place and its contested identities (Wright 1887, Spooner 1895, Te Aroha Borough Council 1980).

For Lisdoonvarna, a similar range of historical source documents included material from local histories, national spa guides and colonial accounts (Hembry 1997, Dooley-Shannon 1998, Furlong 2006). In addition, summaries of the minutes of the local management companies in both towns were valuable sources, as were more experiential material found in travellers' accounts and historic photographs (Cowie 1888, Lynd 1998, Foley 2010). Information on local social and cultural practices, recounted in both official and unofficial documentation, was used to identify clienteles, specific curative practices and wider social behaviours. Given the nature of the colonisers' descriptions, the narratives of the native occupants, Māori and Irish, were often overlooked. These remained a strong presence, yet evidence was hard to come by given the predominantly oral nature of both cultures at that time. 
Table 1. Comparative Spa Town Elements: Lisdoonvarna and Te Aroha

\begin{tabular}{|c|c|c|}
\hline Element & Lisdoonvarna (Ireland) & Te Aroha (New Zealand) \\
\hline Initial Development & $1860 \mathrm{~s}$ and $1870 \mathrm{~s}$ & $1880 \mathrm{~s}$ \\
\hline Peak Period & $1880-1920$ & $1890-1920$ \\
\hline Type of Water & $\begin{array}{l}\text { Cold: Chalybeate, Sulphur, } \\
\text { Copper, Magnesium }\end{array}$ & $\begin{array}{l}\text { Warm: Alkaline with Soda, } \\
\text { Chalybeate, Sulphur (trace) }\end{array}$ \\
\hline Key Buildings & $\begin{array}{l}\text { Hotels, Guest Houses, } \\
\text { Treatment Rooms, Assembly } \\
\text { Rooms }\end{array}$ & $\begin{array}{l}\text { Hotels, Guest Houses, Treatment } \\
\text { Rooms, Assembly Rooms, Bath } \\
\text { Houses }\end{array}$ \\
\hline Curative Services & $\begin{array}{l}\text { Hydropathy, Electrical baths, } \\
\text { Spa doctor }\end{array}$ & $\begin{array}{l}\text { Hydropathy, Electrical baths, Spa } \\
\text { doctor }\end{array}$ \\
\hline Listed Cures & $\begin{array}{l}\text { Rheumatism, paralysis, } \\
\text { neuralgia, sciatica, gout, skin } \\
\text { diseases, gravel }\end{array}$ & $\begin{array}{l}\text { Skin diseases, acne, eczema, } \\
\text { rheumatism, gout, scrofulous } \\
\text { swellings, bone diseases }\end{array}$ \\
\hline Clienteles & Anglo-Irish (Colonial Settlers) & Colonial Settlers \\
\hline Access & Road, Steamer, Indirect Rail & Road, Steamer, Direct Rail \\
\hline Practices & $\begin{array}{l}\text { Imbibing, Walking, Dancing, } \\
\text { Bathing }\end{array}$ & $\begin{array}{l}\text { Imbibing, Walking, Climbing, } \\
\text { Dancing, Bathing }\end{array}$ \\
\hline Liminal Elements & $\begin{array}{l}\text { Drink, Romance, } \\
\text { Revolutionaries }\end{array}$ & Drink, Romance, Revolutionaries \\
\hline Compared with & Harrogate & Vichy \\
\hline Contestations & $\begin{array}{l}\text { Health superceded by Social } \\
\text { meanings }\end{array}$ & $\begin{array}{l}\text { Health and Social meanings about } \\
\text { the same }\end{array}$ \\
\hline Exclusions & Native Irish & Native Maori \\
\hline Contemporary Status & $\begin{array}{l}\text { Heritage \& Tourism, Waters still } \\
\text { potable }\end{array}$ & $\begin{array}{l}\text { Heritage \& Tourism, Waters still } \\
\text { potable, Hot pools }\end{array}$ \\
\hline
\end{tabular}

\section{Core themes}

\section{Selling health}

As recently as five years ago Te Aroha was, but to a very few persons, a Terra Incognita, but the facts of several remarkable cures... having been published and proven to have been effected by the hot mineral springs which are here situated, soon began to bring it into favourable image... during the past three years many sufferers have resorted thereto from all quarters, and in many instances have returned to their homes completely restored to health. These have... personally testified to the wonderfully curative properties of the Te Aroha thermal waters, their fame thus becoming extended further and wider (Wright 1887, n.p.).

The above passage from Dr Alfred Wright's Te Aroha: Its thermal mineral waters was published for the Hot Springs Domain Board that employed him as a physician (Wells 2003). The figure of the spa doctor loomed large in many spa town narratives, while plans for the development of Te Aroha are clearly enunciated in the above quote (Mackaman 1998). The centrality of the 'several remarkable cures' was always the starting point around which key interested parties including local hoteliers, entrepreneurs and medical men, linked the 'health-giving' waters to the marketing discourses central to their development. In addition, the medical credentials of Dr Wright as well as references to 'many sufferers... completely restored to health', add authority to early discourses of the spa as a quality therapeutic resort. The entrepreneurial vision of 
early figures and their influence on the Domain Board were reflected in aspirational claims that the water's, 'medicinal and therapeutic properties are such as cannot fail to bring them into the highest repute, and as their rare virtues become more generally known, it is confidently expected that Te Aroha is destined ere long to become the chief sanatorium of the Australasian colonies' (Wright 1887, Ingram 1892). Spooner (1895) subtitles his booklet on Te Aroha 'the sanatorium of the million' and 'the most popular health resort of the Southern Hemisphere'. To deepen narratives of healing reputation, specific cures were always explicitly listed, 'Many marvellous cures have been effected by the springs and by drinking the waters, more especially... rheumatism, paralysis, neuralgia, sciatica, gout, skin diseases, gravel etcetera' (Ingram 1892). The common 'patient biography' tactic was also used with testimonials of people returning to 'near perfect health' included to support the healing claims (Wright 1887).

A later 1924 brochure from the Department of Tourist and Health Resorts claimed Te Aroha to be one of the country's principal resorts. The description of the town and its location were similar to those from 30 years previously: photographs of a bustling Domain were depicted along with the nearby forest park, within which Mount Te Aroha was given a prominent place. Recreational activities continued to be colonially inspired and similar to those of the late-nineteenth century. From a specifically curative perspective, the description of the mineral waters and baths identified alkaline and bicarbonate baths as still the most abundant and important. A particular selling point was that unlike the larger springs at Rotorua, Te Aroha's springs were not sulphuric. More significantly, various electrical massage treatments were introduced, with qualified staff members employed to administer these treatments (Wells 2003). This age of electrotherapy represented an increasingly medicalised role in the selling of health-in-place. In addition, marketing Te Aroha's spring water, arguably the core medicinal product, involved a range of entrepreneurs who in time were subsumed into the soft drink industry (Rockel 1986). Wells (2003) also notes the contestations associated with the potential benefits from drinking mineral waters, and indeed that these are still debated. Today, the water from the drinking pump holds mere novelty value, as is the case at Lisdoonvarna.

At Lisdoonvarna, narratives identifying the specific make-up of the mineral waters, and subsequent direct linkage to a set of cures and treatments were told and sold in almost identical ways. The different springs, chalybeate, copper and sulphur, did not mimic Te Aroha's unusual soda content, but provided similar cures, being considered, 'most efficacious in cases of scaly skin diseases, in acne and eczema, in chronic rheumatism, rheumatic and atomic gout, scrofulous swellings, also in some diseases of bones and joints' (Mapother 1871). Over time the waters were augmented by a set of treatments, and these were specifically associated with the same forms of 'patient biography' encountered in New Zealand. A local doctor, Edgar Flinn, noted that, 'Personally, I am aware of patients who after several courses of treatment at Harrogate pronounced that they got more benefit and personal relief from the Lisdoonvarna waters than any other' (O'Carroll 1982, p. 13). The latter half of the nineteenth century marked the arrival of a specific 'spa doctor', William Henry Stackpoole Westropp. He updated the dispensing methods for the sulphur springs and introduced bath pumps for both hot and cold baths. As in Te Aroha, there was a distinct shift towards more medicalised hydrotherapies from the end of the nineteenth century, supervised from the doctor's residence, Maiville House, built in 1876 directly above the sulphur wells (Figure 5). These mobile health narratives 


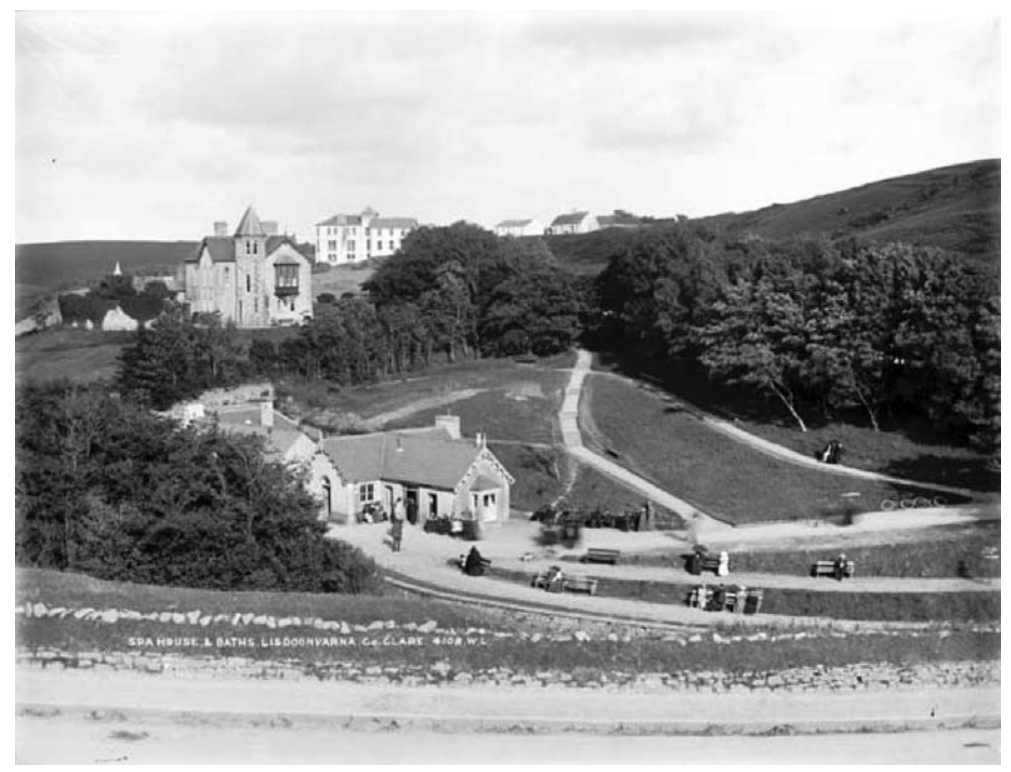

Figure 5. Gowlaun Well and spa doctor's house, Lisdoonvarna.

reflected a shifting focus from natural healing waters to more produced forms including electrical baths that created a new 'currency of health'. As noted in a historical guide from the turn of the twentieth century, Lisdoonvarna had developed its selling of health so that:

The curative treatments now available and yearly being improved and supplemented, comprise, in addition to the hot and cold sulphur water baths, the needle bath, the general electric; the Schnee bath (Galvanic, Faradic or combined), Ionization and electro massage. Various medicated baths as prescribed, are also given, such as Acid Alkaline, Bran, Pine, Peat, Nauheim (Dooley-Shannon 1998).

While the relative power and importance of the traditional Anglo-Irish clientele at Lisdoonvarna was waning, nonetheless the early decades of the twentieth century still saw the town at a relative zenith as marked by a visit by the Lord Lieutenant in 1906 to reopen the Thomond Hotel. A range of treatments, sulphur baths and the various waters continued to be avidly consumed in the summer season (Keena 2007). A new clientele of middle class farmers and professionals emerged in the early decades of the new Irish Free State and carried on the health practices in place. But the economic downturn after World War II and improvements in wider health care provision put paid to the town's traditional healing function (Furlong 2006). It is still possible in summertime to consume the sulphur waters at Lisdoonvarna and bottled water is still sold on site, but that process is now primarily a heritage function.

\section{Selling place}

In both settings the telling and selling of health was inextricably connected to the selling of place. The metaphors of the therapeutic landscape were in part framed by 
their therapeutically verifiable dimension but just as much in the social and cultural landscape of the towns and their surrounds (Foley 2010). In addition there were elements of more deliberate forms of tourism/place building bound up in the development of the spa town. This was easier in towns such as Spa or Baden-Baden, where long-established reputations provided enduring economic support. Tourism/ place building was harder to reproduce on the fringes of Empire. While it was left to individual landowners and entrepreneurs to sell their 'own' watering-places, there was a more deliberate state function in other settings, especially in New Zealand. Dr Arthur Stanley Wohlmann was appointed as the first official Government Balneologist in 1902. His positioning within a new department named Tourist and Health Resorts neatly encapsulated the dual functions of health and place selling (Johnson 1990). This development was a variation to the processes encountered in other countries where that place promotion was 'bottom up' rather than 'top down' (Porter 1990). Additional spatial factors, including the physical setting and surrounding therapeutic landscape, location, transport infrastructures and catchments all played a role in the production of the watering-place. Finally more imaginative connections were also central to the selling of place, wherein anticipated social and cultural encounters were a major driver for the reputation and popularity of the associated resort (Foley 2010).

In selling Te Aroha as a healthy place, the wider setting of the Domain was a significant factor in discussions of the power of nature and landscape. Both Spooner (1895) and Wright (1887) discuss 'majestic' Mt Te Aroha, asserting that it provides the 'grandest, most romantic and extensive views in the province' (Spooner 1895), while Wright (1887) comments that the mountain is accessible to those with 'ordinary powers'. Native forest, scenery, the river and gardens are positively discussed by these writers, and associated with the therapeutic quality of the place. Ingram (1892) describes the Domain as, '. . laid out in a most attractive manner, the winding walks being romantic and attractive, including paths, flower-beds and seating', representing an early form of therapeutic design which reflects Gesler's (1993) identification of the natural and built dimensions of a therapeutic landscape. A government-appointed board was responsible for managing the springs and Domain, with responsibilities for improvements and beautification (Ingram 1892). Te Aroha's climate was also included in varying discourses on its healing properties and overall quality, which Ingram (1892) describes as being 'most healthful, invigorating and enjoyable' throughout the year. Under 'new landlords', Te Aroha's later spa era, in which the arrival of the railway played a prominent part, marked a significant new phase (Rockel 1986, Wells 2003). Here the connection of the town to its catchment 'markets' in Auckland and Hamilton saw it prosper temporarily before a more powerfully promoted place, Rotorua, took both reputational and economic precedence (Johnson 1990). Indeed a particular example of how these different elements coincided was the introduction of special invalid carriages on the Auckland-Te Aroha trains in the late-nineteenth century (Wells 2003). Prior to this time, travelling to Te Aroha from Auckland involved a seven-hour train journey, or taking a steamer and coach via the Firth of Thames and Paeroa. The deeper telling and selling of place involved an attempt to make Te Aroha into a 'world class resort'. Class-related ideologies, the formation of the Domain Board, and legislation to banish animals from the Domain (Wells 2003) represented a significant reordering of space in Te Aroha and the construction of a specific kind of healing place suited to 
a certain clientele. The invocation of other spas and water quality comparisons; a common global aspect of spa towns, was used in Te Aroha. European spas such as Vichy were regularly invoked in posters and promotional material (Mackaman 1998, Foley 2010).

Despite its greater proximity to the 'colonial metropole', it was equally difficult for Lisdoonvarna to sell itself in competition with more established spas (Hembry 1997). In part this was due to the perception, at least in colonial eyes, of Ireland's general backwardness. An account by Barry (1998) of an 1864 visit noted that only one of the five wells was attended and that the Lisdoonvarna spring waters needed upgrading, "under cover of a splendid saloon, and be made to issue from the mouth of a nymph, a lion or the like', to attract English visitors. Despite considerable local attempts to develop the springs and a large increase in the number of visitors in the 1870 s and 1880 s, a scathing comment from a European guide noted, 'Ireland is very poor in wells of all kinds. The wells of Swanlinbar and of Lisdoonvarna scarcely deserve mention, as far as their mineralisation is concerned, nor do they offer such accommodation as can attract strangers' (McPherson 1869 cited in Henchy 1958, p. 210). Despite these external dismissals, the town did expand the number of hotels, the individual wells themselves, as well as associated elements such as pavilions, promenades and a local park reminiscent of the 'Kurpark' ('cure parks') found in German spas (Keena 2007). Chemical and medical analyses were regularly reproduced to further sell the town's virtues, at least to domestic markets. Visitor numbers expanded from around 1,500 in 1870 to 5,000 in 1878 and rose to 18,000 in 1896 (Dooley-Shannon 1998). One significant change in this period was the slow transfer of the ownership and management of the wells from the original landowners, the Stacpooles, to a Local Improvements Committee (Dooley-Shannon 1998).

Unlike Te Aroha, the setting was less celebrated and was described by Hembry (1997) as, 'a straggling, unprepossessing place in bleak and uninteresting surrounding country', while other accounts noted the climate as 'bracing' (Weber and ParkesWeber 1898). In time the town's proximity to the sea became an additional selling point as coastal watering-places became more popular (Kelly 2009). Whereas Te Aroha benefited from the arrival of a direct rail link to the nearby metropolis, Auckland, Lisdoonvarna was never directly connected by train and the nearest that the West Clare Railway got to it was a station at Ennistymon, seven miles away. A set of 'carmen' were on hand there to transport people to the spa while a popular route prior to the arrival of the railway was to go by train to Galway, take a steamer across the bay (reflecting earlier routes to Te Aroha) and then travel on by car (often sponsored by the individual hotels) from small harbours on the North Clare coast (Furlong 2006).

A core promotional document in both settings was the tourist guide, wherein both the health and social facilities were listed and invariably over-praised. Guides to Te Aroha from the late 1800 s emphasise beliefs about the healing qualities of the springs and the town. Ingram's 1892 Guide for invalids provides an introduction to the place and its healing waters, where, '...Te Aroha hot Springs have, within a remarkably short period, gained for themselves, by their wonderful curative powers, a deservedly very high reputation among sanatoria of New Zealand, and their fame is everyday extending to the sister colonies'. Ingram (1892) and Wright (1887) both asserted that sufferers of 'nervous disorders... can obtain perfect serenity and repose'. The baths, buildings and drinking springs were thoroughly described, including their 
temperatures, minerals and disorders they would purportedly cure. Spooner's 1895 guide provides an analysis and technical description of the spring's chemical composition along with treatment capabilities and recommendations. While guesswork may have been involved, proponents of the healing waters were enthusiastic advocates of their quality and more specifically in how the waters should be applied, under scientific-medical guidance, to heal. According to Wright (1887, n.p.):

The mineral waters are exceedingly interesting and will prove of great value medically. They closely resemble some of the European mineral springs so justly celebrated... You may rest assured that all you can do for your springs in the shape of improving the facilities for their use is entirely justified by the character of the water.

While the waters of Lisdoonvarna were compared to other spas, in particular in an 1875 report which pointed out that the sulphur spring was three times more powerful than that of Harrogate, it seemed as if wider aspirations were limited given its relatively late development in the wider cycles of spa histories (Dwyer 1998, Kelly 2009, Foley 2010). The role of reputation and the wider narrative powers of the place were regularly invoked however, 'The wonderful cures which result from these spas are everywhere spoken of. One thing is certain, that a fortnight spent at Lisdoonvarna renews the constitution, gives new energy and animation, and the invalid in most instances leaves a place which has made a new man of him in every respect' (Anonymous 1863). It should also be noted that there were considerable contrasts between the negative accounts of Lisdoonvarna in British publications and more positive local publications such as $A$ Handbook to Lisdoonvarna and its vicinity, written in 1876 under the pseudonym P.D. This more focused text was eager to acknowledge that the chapter on the Medicinal properties and effects of the spas of Lisdoonvarna was the work of Dr Westropp of Lisdoonvarna, while the expressed purpose of the guide was a perceived duty to 'to alleviate human suffering and to promote innocent recreation' (O'Ceirin 1998).

\section{Contested identities: Healthlleisure}

As was the case in most spa towns, the curative reputations and purported power of the springs' minerals were only one part of the story. Just as in more elegant and established settings like Bath, Spa or Carlsbad (Karlovy Vary), the seasonal inhabitations and practices encountered in place were as much social as medicinal. One key reason to visit a spa was to meet others of one's own social station and have a pleasant break from normal routines. In addition the locations of the spa, neutral settings where one could expand one's own circle of contacts, marked them as liminal spaces. One example was the specific identity of a spa town as a site of potential romantic contact (Mackaman 1998, Foley 2010). Evidence for this is less clear in Te Aroha (though the name means 'love' in Māori and hot springs were traditional sites for encounters between young Māori men and women) given the less classed character of New Zealand society. The social function of Lisdoonvarna as a site of 'matrimonial promise' did, however, reflect wider spa narratives. Given the relative dispersal of the small but powerful Anglo-Irish class across Ireland, the wateringplace was a convenient site for prolonged exposure to potential partners, both in business and pleasure. It might be reasonable to assume that Te Aroha played a 
similar function for Pakeha (white settler) society in New Zealand. In both cases the extended seasonal visits to the spa and associated performative practices of promenading, dining, dancing and drinking (of both mineral waters and stronger spirits) created spaces for connections to be made (Wells 2003). It should be noted that these socialised practices were often a direct contestation of the curative ones so that the gains made by drinking the recommended 'two to eight tumblers' of water (1 to 4 pints) in the morning might be wiped out by the embodied losses sustained in a night's claret drinking and card-playing. Te Aroha's proximity to nearby gold-fields and the relative lawlessness of early colonial society was slowly transformed to a more socially-ordered place, within which the waters and treatments had an increasing role. It would be fair to say that Te Aroha did not have the same reputation for alcohol or liminality as at Lisdoonvarna, where the social excesses became part of the town's identity and saw it described as being 'like Lourdes in the morning and Monte-Carlo at night' (Keena 2007). While this was in part a comment on the increased presence of clerics of all denominations, the all-night dancing and gambling became central to the town's identity. Even in the twenty-first century the town's matrimonial reputation has been sustained into a month-long festival in September of each year. This tradition, with regularly shifting clienteles, has lasted from the Anglo-Irish period of the mid-nineteenth century into the present day (Keena 2007).

Equally significantly, the relative importance of social over medicinal identities was also shaped by a wider narrative, wherein spa medicine in general was slowly discredited by the newly-professionalised medical classes. Even though curative practices changed over time and increased medicalisation became a feature in both towns, The Lancet continued to lampoon the assumed quackery and dubious outcomes associated with the spa (Price 1981). Thus, in Lisdoonvarna, a qualified approval was given in a report from 1902 but only to the sulphur springs, the other's being considered medically unreliable or unproven (Hembry 1997). Given that the development and management of spa medicine in New Zealand was explicitly linked to a governmental development of 'health tourism', the town's health and leisure identities were deliberately blurred, with both identities given equal formal prominence. As a result it is less easy to identify a judgemental 'medical gaze' being turned onto Te Aroha's waters, with the wider merits of the location being given equal value. Wells (2003) discusses a questioning of the curative powers of the mineral waters and the wide range of 'hydropathists' using them, from medical doctors to quacks. He suggested that hydropathy undoubtedly improved some medical conditions, with warm bathing and bicarbonate in the drinking water being the main benefactors at work. But the evidence largely entailed guesswork and the idea of mineral elements curing specific ailments was relatively unfounded in a scientific sense.

\section{Contested identities: Coloniallnative}

As a second form of contestation, it is also valuable to consider the different cultural groups who met and mingled in such settings. While most spa towns in Europe had relatively elitist clienteles, at least in their initial formations, and these shaped a form of class-based 'inhabited ownership', contestations of space became more apparent at the colonial spa. Although a much less dominant narrative in Te Aroha, healing 


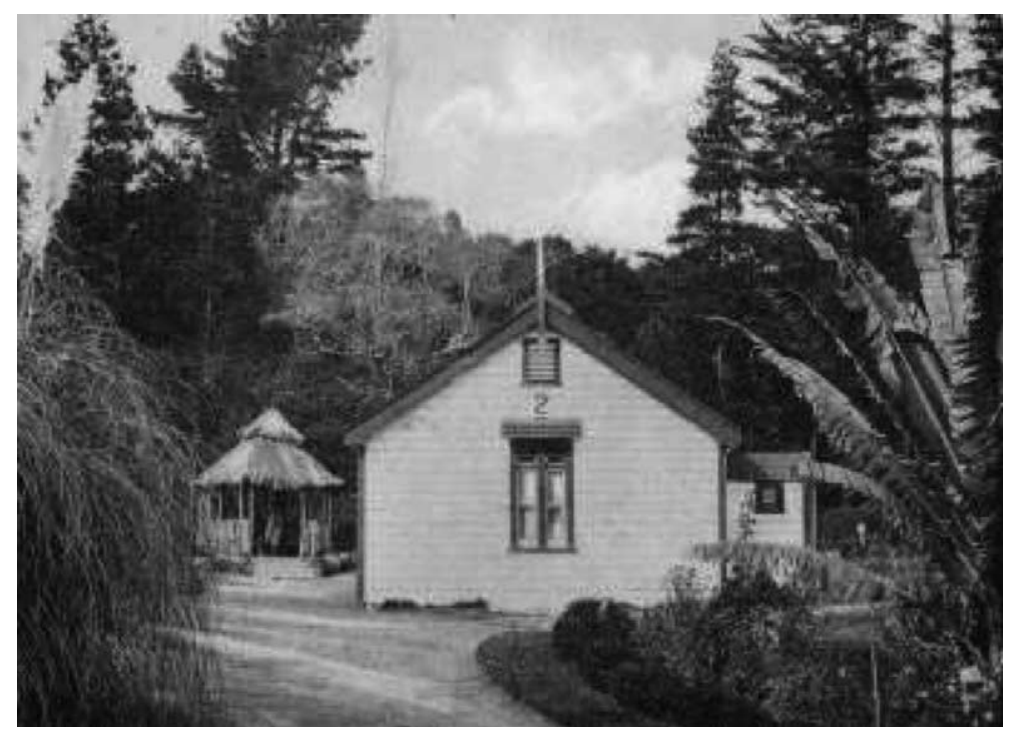

Figure 6. Māori Bath-house No. 7, Te Aroha.

associations and journeys could be traced back to pre-European history. Wells (2003) identified over 600 years of Māori presence in the Hauraki region and a widespread regional knowledge of the waters, including spiritual meanings, land connections, relief from aches and pains, and use for pleasure. Thus, Te Aroha served as a local healing place long before it was adopted and developed into a spa town by Europeans (Te Aroha Borough Council 1980). Wells (2003) discusses discriminatory attitudes within spa-era Te Aroha and the segregation of Māori to a designated bathhouse, where the relative 'whiteness' of Te Aroha served as a point of assumed superiority. Wright's brochure (1887) discusses ladies' usage (times and spaces), areas suitable for children, and Māori, where 'a bath-house a distance from the rest. . . is set apart for the sole use of natives'. The construction and assignation of the No. 7 bath house (Figure 6) further signals the particular ordering of space in constructing the spa town of old. In addition the ambiguous word 'apart' can be read simultaneously as being excluded (apart) and included (a part) in the same space. Thus, a definite, if often overlooked cultural aspect and alternative story and significance can be traced within the construction of Te Aroha as a therapeutic space (Wilson 2003). It was also the case that indigenous Māori knowledge and therapeutic practices were much less fully used in the subsequent branding of Te Aroha than in Rotorua, a town seen as less British in its character and identity (Wells 2003).

This sense of ambiguous positionality was also evident in Lisdoonvarna, though perhaps less visibly marked than in Te Aroha. Indeed there were different responses to exclusion here when, in 1867 the Anglo-Irish landlord, Stacpoole, attempted to block access to the spa waters. This was met with a literally explosive response with newly built locked gates being blown up in the middle of the night. This was partly a political response given that, 'These were Fenian times and the right of public access was asserted by dynamite' (O'Ceirin 1998). While the natives worked at the spa, they 
were there to serve the wealthier clienteles. Even a local character such as 'Biddy the Sulphur', a local woman who doled out waters at the pump-room, was actually a relative of the landowning family. Gradually in the early-twentieth century, these contestations of ownership saw the management of the wells passed across to a local committee (after a lengthy legal struggle) and this more collective ownership fed through into the newly independent state after 1922, and up to the present day. This more co-operative ownership model developed in Te Aroha too, although it was not until much more recent times that Māori rights were reasserted. Te Aroha also reflected the slow shift across to more democratic local utilisations at Lisdoonvarna, as local farmers from the Waikato plains became significant visitors to the town and sustained its activities. While it is tempting to frame these examples of contestation as 'local/inclusive' versus 'colonial/exclusive' dualities, the narratives were always more complex on the ground. The local resistances in Ireland were reflected in the successful campaigns to keep the waters free and open. Yet during World War I, a request to the Lisdoonvarna Improvements Committee in 1916 to use the town as a rehabilitation centre for wounded troops (common elsewhere in Ireland and Scotland) was declined (Dooley-Shannon 1998, Durie 2006). The 'place' of the Māori at Te Aroha was also ambivalent, given that access to the springs was originally granted by a Māori chief. Yet at the same time an early visitor to the spa identified that its best prospect of success lay in the 'the absence of Māoris and the presence of a railway' as key ingredients (Wells 2003, p. 15).

\section{Discussion}

In a relational sense, the colonial spa sat in a space which was distant from the metropole, but also distant from more centralised models of spa town networks in mainland Europe. While attempts were made to replicate and reproduce the typical spa town ensemble observable elsewhere, local and unique elements also shaped practice and form. Thus Te Aroha's and Lisdoonvarna's locations rendered them both geographically and culturally remote, which in turn shaped the cures and health care performances found in the two towns. While competition played a role in the telling and selling of health in both settings, these practises were also framed by place characteristics and the entrepreneurial alliances involved in that production. The wider circulations of health paradigms, as nature-based water medicine was replaced by hydrotherapy and increasingly biomedical discourses, were observable in both settings, despite their enormous geographical separation. This tension between the relational in both spatial and cultural terms was also visible in the contestation of native/othered spaces. Indeed the connections between the sites also allow them to be seen as what Hoyez (2007) refers to as 'globalising therapeutic landscapes', wherein cultural forms are reproduced across vast distances which often bear little relationship to specific local settings.

The mineral water resources in both towns were central to the changing ideas, practices and place constructions regarding health and well-being. In establishing facilities and a healing reputation, Te Aroha's spa town settlement originated and was organised around mineral springs. This project of establishing the antipodean spa scene in New Zealand was one way in which colonialism could be inscribed upon, and reflected in, the landscape. The process of creating the envisaged scene involved not only building place in physical terms. Attracting clients as well as 
reputed experts and using their narratives to promote townships like Te Aroha was also an essential endeavour. It was hoped that New Zealand spas would come to rival the famed resorts of the Northern Hemisphere, given the long history of thermal watering places in Europe (Rockel 1986). The traditional patronage of these spa towns was mostly comprised of society's upper classes, and along with serving as locations for therapy, spas were also places to see and be seen (Mackaman 1998). In addition, travel and tourism for health and well-being remained significant dimensions of spa cultures. The extent to which this remained the case with respect to Te Aroha, was a central question. The transposing of spa culture onto a burgeoning New Zealand society and rural landscape entailed the challenge of applying its principles within a quite different context (see Rockel 1986).

While closer to the metropole, Lisdoonvarna was ironically even more marginal than Te Aroha. Both suffered deeply from a lack of fashionability, a core and understated element in the reputationally-formed therapeutic landscape of the spa town. Scale, proximity and competition from other therapeutic landscapes were also significant. In Lisdoonvarna's case it suffered direct competition from both British and Continental European watering-places but also from sea-bathing resorts closer to home (Foley 2010). For Te Aroha, the competition came from Australian spas like Daylesford but also from the expanding resort of Rotorua, heavily promoted by Wohlmann, the government-appointed Balneologist, who focused much of his energies on that resort (Johnson 1990). The reputation of many a European spa was founded on royal patronage (Cossick and Galliou 2006). In the case of both Te Aroha and Lisdoonvarna the nearest they came was a visit from the de facto heads of state, the Lords Lieutenant, in each jurisdiction. A visit to Lisdoonvarna in 1906 by Lord Aberdeen, the Lord Lieutenant of Ireland was regarded as providing a significant boost to business, whereas a very early visit by Lord Grey, the Lord Lieutenant of New Zealand to the waters of Te Aroha as early as 1849, was considered, in hindsight, to have been a lost opportunity (Wells 2003, Furlong 2006). Yet both sites also had more dissident political associations. A visit by the 'infamous' leader Te Kooti to Te Aroha, where he was warmly welcomed by local iwi (Māori tribal groups) was negatively reported in the wider press. A parallel dissident identity was reflected in the use of the Spa Assembly rooms of Lisdoonvarna for a revolutionary speech by Eamon de Valera in 1919 (Dooley-Shannon 1998).

Early promoters of the spa sought to boost Te Aroha's credibility as a therapeutic space via 'scientific' analysis of the waters and medicalised discourses around their application. As well as the waters, wider place qualities were included in the constructed healing package, with testimonials being a significant factor in the assertion of therapeutic effects. The healing benefits of the waters and framings as a therapeutic space were at the heart of the tourism that was essential to Te Aroha's earlier days. Subsequent decades saw a decline of the spa and, following World War II, the town functioned as a rural service centre, connected into the Waikato's agricultural industry until the end of the 'long-boom' period of unprecedented economic growth in the 1950s and 1960s. It was not until the years following socioeconomic restructuring that the heritage value of Te Aroha's spa era was recognised and became a major aspect of the re-emergence of tourism efforts in the town.

A surprisingly similar history was evident in Lisdoonvarna in the 1930s and 1940s, though in its wider economy Ireland, unlike New Zealand, remained relatively stagnant. While the Matrimonial Festival kept up some sort of seasonal business in 
September, it too functioned as a small rural service centre, but without the same richness of agricultural land. But like Te Aroha, there was recognition of heritage value and various ambitious plans were made in the 1970s to revive the town through the development of a specialist centre for rheumatic disease. Ironically a part of that proposed development saw the town seek, in what might be termed a "post-postcolonial' move, to rejoin the British Spa Federation (Clare Champion 1996). In a quite different sense, and after rapid colonisation, spa development and ensuing decline, Māori are now reasserting the importance of the waters at Te Aroha (Wells 2003). The connection between healing at different (and holistic) levels, and for groups as opposed to only individuals, is worth mentioning here in both a curative and a commercial sense. The springs' healing qualities are not only sought by Māori for physical comfort, but also to relieve grievances around ownership and the dishonouring of the original partnership agreement regarding the Domain.

\section{Conclusion}

In both Te Aroha and Lisdoonvarna, the identification of parallel 'sellings' and 'tellings' of health/place linkages was a prime motivation for the investigation. In considering the historical development of both towns, a commodifying cycle of discovery-authentication-promotion-development was apparent, with the final stage in particular being marked by a parallel social dimension which produced similar identities and narratives of place. We have noted tensions in how health and place were sold in both places and shown that competing narratives were key to place production (Gesler 2003).

Contested identities of place were also framed by social behaviours and the commercial exploitation of visitors to the sites. Te Aroha never seemed to have the same liminal reputation as Lisdoonvarna, though perhaps this was in part due to the relatively settled nature of society in New Zealand in the later nineteenth century. In addition there was an ongoing tension in both settings in the development of a more medicalised hydrotherapy, which contrasted with more holistic indigenous understandings of the healing power of water. However, the stories of both spa towns reveal similar trajectories and discourses of contestation around their holistic and biomedical beliefs, as well as between their curative and social reputations and colonial and native inhabitations. Yet even these are often false dichotomies in that the different identities and dimensions of the towns were deeply embedded and intertwined. While the contestations became clearer or were elided over time, they still reflected the fact that the framing of spa towns as globalised therapeutic landscapes was also balanced around these elements. The social identities of the spa were founded on their formative meanings as therapeutic places, while their development could not have been sustained without them being sold as sites of liminality, leisure and pleasure (Towner 1996, Gesler 2003, Foley 2010).

While there were significant variations in the settings, both geographical (one had hot springs, the other cold) and commercial between the two towns, there were also surprising commonalities around the production of classic colonial watering-places. In this they were identifiably typical and unique. It might be useful to extend this consideration of the colonial spa town to other specific towns in the two jurisdictions, though places like Rotorua and Mallow had unique characteristics of their own (Myers 1984, Rockel 1986). It might also be valuable to consider how spa 
towns were 'sold' and 'told' within the wider colonial cultures within which such towns were situated (Gesler 2003).

Finally, the common ways in which spa towns emerged as cultural forms in countries without colonies might be considered in terms of cultural, rather than political, influence. The great European spas of Baden-Baden and Carlsbad remained a model, equally contested in their medicinal and liminal identities, against which smaller spas measured themselves (Porter 1990). Finally the model of the wider European or Anglophone spa might be usefully considered in relation to other cultural forms of watering place such as hammams or sauna which operate in different scales and settings in the Arab and Scandinavian worlds (Aaland 1978). In revisiting these traditional forms of water-based therapeutic landscapes, more contemporary notions of contestation, inhabitation and performance can be (re)placed within a wider consideration of culture, health and place (Gesler and Kearns 2002, Williams 2007).

\section{Acknowledgements}

University of Auckland, Matamata-Piko District Council, National University of Ireland, Maynooth, Trinity College Dublin, University College Dublin, Lisdoonvarna Town Council, Clare County Council Records Office, University of Limerick.

\section{References}

Aaland, M., 1978. Sweat. Santa Barbara, CA: Capra Press.

Andrews, G. and Holmes, D., 2007. Gay bathhouses: The transgression of health in therapeutic places. In: A. Williams, ed. Therapeutic landscapes. Aldershot: Ashgate, 221232.

Anonymous. 1863. Lisdoonvarna. Limerick Reporter and Tipperary Vindicator, 25 August, no page number.

Barry, W., 1998 [1864]. A walking tour of Clare, 1864. In: B. Ó Dálaigh, ed. The stranger's gaze: Travels in County Clare 1534-1911. Ennis: Clasp Press, 275-281.

Brockliss, L.W.B., 1990. The development of the spa in seventeenth-century France. In: R. Porter, ed. Medical history, supplement no. 10. London: Wellcome Institute for the History of Medicine, 23-47.

Clare Champion, 1996. Lisdoon hosts meeting of Spa People. Clare Champion, 18 October 1996, p. XII.

Collins, D. and Kearns, R., 2007. Ambiguous landscapes: Sun, risk and recreation on New Zealand beaches. In: A. Williams, ed. Therapeutic landscapes. Aldershot: Ashgate, 15-32.

Conradson, D., 2005. Landscape, care and the relational self: Therapeutic encounters in rural England. Health \& Place, 11 (4), 337-348.

Connell, J., 2006. Medical tourism: Sea, sun, sand and ... surgery. Tourism Management, 27 (6), 1093-1100.

Cossick, A. and Galliou P., eds. 2006. Spas in Britain and in France in the eighteenth and nineteenth centuries. Newcastle-upon-Tyne: Cambridge Scholars.

Cowie, W.G., 1888. Our last year in New Zealand, 1887. London: Kegan, Paul, Trench \& Co.

Curtis, S., Gesler, W., Fabian, K., Francis, S., and Priebe, S., 2007. Therapeutic landscapes in hospital design: A qualitative assessment by staff and service users of the design of a new mental health inpatient unit. Environment and Planning C, 25 (4), 591-610.

Dooley-Shannon, M., 1998. The historical development of tourism in Clare: Portrait of a spa town - Lisdoonvarna, 1800-1914. Unpublished MA Thesis. University of Limerick.

Durie, A., 2006. Water is best: The hydros and health tourism in Scotland 1840-1940. Edinburgh: John Donald.

Dwyer, P., 1998 [1876]. A handbook to Lisdoonvarna and its vicinity. Ennis: Clasp Press. 
Foley, R., 2010. Healing waters: Therapeutic landscapes in historic and contemporary Ireland. Aldershot: Ashgate.

Furlong, I., 2006. The saga of Lisdoonvarna - 'From queen of Irish spas' to modern matchmaking mecca. In: A. Cossick and P. Galliou, eds. Spas in Britain and in France in the eighteenth and nineteenth centuries. Newcastle-upon-Tyne: Cambridge Scholars, 239-261.

Geores, M.E., 1998. Surviving on metaphor: How 'Health $=$ Hot Springs' created and sustained a town. In: R. Kearns and W. M. Gesler, eds. Putting health into place: Landscape, identity and well-being. Syracuse University Press, 36-52.

Gesler, W.M., 1993. Therapeutic landscapes: Theory and a case study of Epidauros, Greece. Environment and Planning D, 11 (2), 171-189.

Gesler, W.M., 1996. Lourdes: Healing in a place of pilgrimage. Health \& Place, 2 (2), 95-105.

Gesler, W.M., 2003. Healing places. Lanham: Rowman \& Littlefield.

Gesler, W.M. and Kearns, R., 2002. Culture/place/health. London: Routledge.

Hamlin, C., 1990. Chemistry, medicine and the legitimization of English spas, 1740-1840. In: R. Porter, ed. Medical history, supplement no. 10. London: Wellcome Institute for the History of Medicine, 67-81.

Hembry, P., 1997. British spas from 1815 to the present. A social history. London: The Athlone Press.

Henchy, P., 1958. A bibliography of Irish spas. The Bibliographical Society of Ireland, 6 (7), 98-111.

Hoyez, A.-C., 2007. From Rishikesh to Yogaville: The globalization of therapeutic landscapes. In: A. Williams, ed. Therapeutic landscapes. Aldershot: Ashgate, 49-64.

Ingram, J.S., 1892. Guide for invalids to the thermal springs and baths of Te Aroha, New Zealand. Te Aroha: Ingram.

Johnson, R.H., 1990. Arthur Stanley Wohlmann, the first Government Balneologist in New Zealand. In: R. Porter, ed. Medical history, supplement no. 10. London: Wellcome Institute for the History of Medicine, 114-126.

Kearns, R. and Gesler, W.M., eds., 1998. Putting health into place: Landscape, identity and well-being. Syracuse University Press.

Keena, M., 2007. The road to Lisdoonvarna. Lisdoonvarna: Wolf Hill.

Kelly, J., 2009. 'Drinking the waters': Balneotherapeutic medicine in Ireland, 1660-1850. Medicine in $17^{\text {th }}$ and $18^{\text {th }}$ century Ireland. Studia Hibernica, 35, 99-145.

Lea, J., 2008. Retreating to nature: Rethinking 'therapeutic landscapes'. Area, 40 (1), 90-98.

Lynd, R., 1998. [1911]. Rambles in Clare, 1911. In: B. Ó Dálaigh, ed. The strangers gaze: Travels in County Clare, 1534-1950. Ennis: Clasp Press, 325-329.

Mackaman, D.P., 1998. Leisure settings: Bourgeois culture, medicine and the spa in modern France. University of Chicago Press.

Mapother, E.D., 2010 [1871]. The treatment of chronic skin diseases: 3 lects. with an appendix on Lisdoonvarna spas. Charleston, SC: BiblioBazaar.

Myers, K., 1984. The Mallow Spa. Mallow Field Club Journal, 2, 5-19.

O'Carroll, C., 1982. Lisdoonvarna - The development of an Irish spa. The Other Clare, 6, $12-14$.

O'Ceirin, C., 1998 [1876]. Introduction, in Anonymous (P.D.) A handbook to Lisdoonvarna and its vicinity giving a detailed account of its curative waters and tours to the principal places of interest in the County Clare, Reprint. Ennis: Clasp.

Palka, E., 1999. Accessible wilderness as a therapeutic landscape: Experiencing the nature of Denali National Park. In: A. Williams, ed. Therapeutic landscapes: The dynamic between place and wellness. Lanham, MD: University Press of America, 29-51.

Porter, R., 1990. The medical history of waters and spas: Introduction. In: R. Porter, ed. Medical history, supplement no. 10. London: Wellcome Institute for the History of Medicine, vii-xii.

Price, R., 1981. Hydropathy in England, 1840-1870. Medical History, 25 (3), 269-280.

Rockel, I., 1986. Taking the waters. Early spas in New Zealand. Wellington: Government Printing Office.

Rutty, J., 1757. An Essay towards a natural, experimental and medicinal history of the mineral waters of Ireland. Dublin: Unknown publisher. 
Smith, M. and Puczko, L., eds., 2009, Health and wellness tourism. Oxford: ButterworthHeinemann.

Spooner, C.F., 1895. Te Aroha New Zealand. Te Aroha: Te Aroha Hot Springs Domain Board Tourist Booklet.

Sterngrass, J., 2001. First resorts: Pursuing pleasure at Saratoga Springs, Newport and Coney Island. Baltimore, MD: Johns Hopkins University Press.

Strang, V., 2004. The meaning of water. Oxford: Berg.

Te Aroha Borough Council, 1980. This is Te Aroha. Te Aroha: Centennial Publication.

Towner, J., 1996. An historical geography of recreation and tourism in the western world, 15401940. Chichester: John Wiley.

Tuan, Y.-F., 1974. Topophilia: A study of environmental perception, attitudes and values. New York: Columbia University Press.

Urry, J., 2002. The tourist gaze. London: Sage.

Valenza, J. M., 2000. Taking the waters in Texas: Springs, spas and fountains of youth. Austin, TX: University of Texas Press.

Weber, H. and Parkes-Weber, F.P., 1898. The mineral waters and health resorts of Europe. London: Smith, Elder \& Co.

Wells, K., 2003. A postcard from Te Aroha. An account of taking the waters at Te Aroha's Hot Springs Domain. Auckland: Polygraphia.

Wheeler, A., 2008. Place construction and promotion in the evolution of a New Zealand spa town: The case of Te Aroha. Unpublished BA Thesis. University of Auckland.

Wightman, D. and Wall, G., 1985. The Spa experience at Radium Hot Springs. Annals of Tourism Research, 12 (3), 393-416.

Williams, A., 1998. Therapeutic landscapes in holistic medicine. Social Science and Medicine, 46 (9), 1193-1203.

Williams, A., ed., 1999. Therapeutic landscapes: The dynamic between place and wellness. Lanham, MD: University Press of America.

Williams, A., ed., 2007. Therapeutic landscapes. Aldershot: Ashgate.

Wilson, K., 2003. Therapeutic landscapes and First Nations peoples: An exploration of culture, health and place. Health \& Place, 9 (1), 83-93.

Wright, A., 1887. Te Aroha New Zealand: A guide for invalids and visitors to the thermal springs and baths. Te Aroha: Te Aroha Hot Springs Domain Board Tourist Booklet. 